\title{
EL PENSAMIENTO GRIEGO EN LA OBRA DE JOSE GAOS
}

Tal vez no pueda encontrarse filósofo alguno de primera, intermedia o última línea, que no tenga una relación natural, próxima o remota, con el pensamiento griego y sus próceres, padres y maestros del filosofar, por lo menos al modo de Occidente. Parece como un cordón umbilical necesariamente dado (es decir, por el absurdo y la casi imposibilidad de que se ignore el origen de aquello que se vive y cultiva), que enlaza el primer comienzo y una de las más altas cimas de toda filosofía con cualquier otro momento de la misma, individual o colectivo. En un extremo, puede tratarse de lejano impulso o vaga inspiración; en el otro extremo, puede llegar a ser fuente perenne, tesoro inagotable y motor poderoso y constante de la vida del espiritu. En ambos casos y en todos los posibles, el pensamiento de Anaximandro y de Pitágoras, de Heráclito o Parménides, de Anaxágoras y Demócrito, de Sócrates, Platón y Aristóteles, aparece como guía luminosa hacia los valores fundamentales: verdad, conciencia, certeza, espontaneidad, búsqueda, inquietud, ciencia, método, sabiduría, justicia, libertad... Puede recorrerse la historia entera del filosofar y se advertirá cómo siempre han estado presentes de modo manifiesto y eficaz, ora los dos grandes clásicos, con predominio alterno de uno $u$ otro, ora alguno de los demás pensadores importantes, ora las ideas o los movimientos ideológicos mismos.

En lo anterior no me refiero al filólogo, ni al filólogo-filósofo, ni tampoco al filósofo metido a filólogo, todos los cuales por oficio se deben ocupar del pensamiento griego o helénico; sino que me refiero al filósofo o pensador que en su reflexión específica e independiente, llamémosla así, y para su propia concepción del mundo y de la vida, tiene en general presentes las visiones y hallazgos de los griegos. La extensión y profundidad de esa presencia variará, sin duda, en cada caso, y de acuerdo con ella se precisará lo "griego" de un filósofo -en general- y —en particular - lo platónico o aristotélico, lo idealista o realista, lo metafísico o positivo, etc. También serán diversas las vías de acceso y formas de trabajo: desde la meditación sobre sus filosofemas e investigación de sus principios, hasta el comentario y la exégesis, o la simple traducción anotada.

Creo que a través de estos puntos de vista hemos de acercarnos a la obra del maestro y filósofo José Gaos — supuesta, naturalmente, la finalidad perseguida aquil. Pero debe advertirse, desde luego, que el propósito de estudiar este aspecto en él no se apoya simplemente en el hecho general aludido al principio - pudiéndose en la misma forma considerar a todos o a cualquiera 
de los filósofos-, sino que tiene razones especiales, como precisamente tratará de señalarse en estas líneas. Cuánto haya significado la filosofía griega para nuestro filósofo José Gaos, lo iremos viendo, pues, bajo diversos ángulos a través de este ensayo - verdaderamente tal-, de modo indirecto en el contenido mismo, o directo con sus propias palabras. Por ejemplo, siéntanse la intensidad y la hondura de su inclinación por la filosofía y el papel que ahí jugó la griega, expresadas en estas vivas palabras: "Desde la adolescencia, durante ya muy cerca de un cuarto de siglo - bodas de plata- he vivido en trato, primero de relaciones amorosas, luego de ejemplar fidelidad conyugal, con la filosofía. Desde el primer momento, el mismo del encuentro con ella, me atrajo con sus ojos claros de Atenea, su nombre y todo su porte griego -aunque pronto me hizo saber que, si bien de irreprochable ascendencia helénica, en la actualidad era germánica. La amé en definitiva sin demasiadas complicaciones, porque ella misma se me presentaba como afán de saber tan puro y comprensible como sus ojos claros." 1 Lo anterior presenta el matiz colorido de lo subjetivo y personal; las palabras que siguen tienen el valor de la apreciación objetiva: "Esta antología da con este libro [el libro L de la Metafísica], por tanto, el texto en que culmina la filosofía griega y toda la antigua, una de las cumbres más altas de la universal entera; el texto de una doctrina filosófica de incomparable repercusión a lo largo de todas las edades subsiguientes en la historia de la cultura occidental y a lo ancho de toda esta cultura, no dentro de la filosofía sola." 2 (En ambas citas los subrayados son míos.)

Sin embargo, de una manera general podemos anticipar desde ahora los argumentos o hechos que siguen: $1^{9}$ el estudio de Los origenes de la filosofía y de su historia en Herodoto, Platón y Aristóteles, que incluye textos de los dos últimos, traducidos por el maestro; $2^{\circ}$ la traducción de la Metafísica de Aristóteles; $3^{\text {o }}$ la confección de una Antología filosófica exclusivamente con textos de la filosofía griega traducidos por él; ${ }^{3} 4^{\circ}$ referencia frecuente a los puntos de partida griegos en libros como De la filosofia, Del hombre, etc.; $5^{9}$ la enseñanza de la filosofía griega y aun de la lengua griega misma; 4 y $6^{\text {0 }}$ la traducción de obras sobre la filosofía griega, como en especial el libro básico de Jaeger, Aristóteles.

1 Filosofia de la filosofia e Historia de la filosofia, México, 1947, Ed. Stylo, p. 28. En todo este ensayo, las cursivas que aluden al valor del pensamiento griego son mías; las precisivas son del texto.

2 Antología filosófica. La Casa de España en México, México, 1940, p. 45.

3 Parece que el doctor Gaos pensó formar una antologia que abarcara todas las épocas de la filosofía, habiéndose quedado sólo en la griega.

4 Origenes de la filosofía y de su historia, Universidad Veracruzana, Xalapa-México, 1960. Nota a la p. 15. Existe además una carpeta que contiene los apuntes de tres cursos sobre filosofía griega. Por lo que se refiere a la lengua, él la enseñó varios años en la Universidad Femenina de México, utilizando como texto la lectura del libro A de la Metafísica de Aristóteles. 
Otra advertencia necesaria, que precisa a la anterior, corresponde al tipo de trabajo que presentamos. Un estudio completo y profundo sobre lo que el pensamiento griego influye en la filosofía de José Gaos, o más bien quizá, sobre las manifestaciones no sólo de contenido, sino aun formales, referibles a aquél, requeriría precisamente, por una parte, el examen total de lo escrito por el maestro $y$, por otra, una reflexión meditada y una penetración sutil de los aspectos de fondo y forma, contenido y método, de la filosofía griega aparecidos ahí. En estas líneas no se ofrece tal estudio, sino más bien un ensayo de aproximación, a través del cual se destaquen los relieves más conspicuos del contacto de José Gaos con los griegos. ¿Por qué tal actitud? Porque se trata aquí de un escrito programado dentro de un homenaje, circunscrito a límites del espacio donde debe incluirse y del tiempo de preparación del mismo; en cambio, el estudio a que se renuncia requeriría sin duda más tiempo y espacio, así como otros enfoques metódicos.

También se ha tenido en cuenta en esa actitud el problema mismo de la definición o caracterización del pensamiento del maestro. Quiero decir que, si ella fuera evidente o estuviera lograda, resultaría más fácil descubrir el papel que desempeñaran ahí los antecedentes griegos. Con esto, además, me refiero a que uno de los puntos de la caracterización, al menos, podría ser precisamente lo helénico - platónico o aristotélico-, o podría partir de ello. Sin embargo, esa caracterización fundamental o definitiva no se ha hecho aủn, sin duda muy justificadamente, por la falta de una visión a distancia. Atiéndase a que he dicho "fundamental o definitiva", pues no se me oculta lo que en general todo discípulo, seguidor o conocedor de Gaos sabe, es decir, que el historicismo desempeñó un papel central en todo su pensamiento, exceptuando tal vez los tres últimos lustros. ${ }^{5}$

Ciertas características del trabajo filosófico de José Gaos nos inducen a considerar los motivos o propósitos concretos que en las diversas obras lo llevaron a ponerse en contacto con los pensadores griegos - dejando aparte, naturalmente, las razones generales que, como decíamos antes, tendría todo filósofo. Yo creo que pueden distinguirse los propósitos siguientes, basados por lo menos en algún respecto: $1^{\circ}$ el pedagógico, $2^{\circ}$ el fílológico, $3^{\circ}$ el "traductivo" y $4^{\circ}$ el doctrinal o ideológico. Los dos primeros guiaron al maestro sobre todo en la Antologia filosófica y en la traducción de la Metafisica; el tercero, en los mismos trabajos y en la parte textual de los Origenes de la filosofia y de su historia; el cuarto, en los libros De la filosofia y Del hombre, así como en los Origenes y en la introducción a la Antología. Aunque un tanto simplista, voy a seguir en mi exposición el hilo conductor señalado por esos propósitos, pensando que con ello se ganará mucho en objetividad y precisión.

5 Adopto como punto de referencia el tratado De la filosofia, que, aun cuando publicado en 1962, contiene el curso lefdo en 1960 . 
1 Destacar especialmente el aspecto o propósito pedagógico en quien era, según acuerdo unánime, maestro por excelencia, parecería empresa, por una parte, difícil y, por otra, tal vez ociosa. Sin embargo, quizá precisamente este enfoque nos manifieste que hay una relación especial entre su carácter de maestro, con todas sus virtudes humanas, su capacidad, sus conocimientos y su instrumental metódico, y la filosofía griega, con su pristinidad y espontaneidad. Por principio de cuentas, es un hecho la preferencia mostrada por él hacia los textos griegos para la propedéutica -es decir, la iniciaciónfilosófica y la utilización que hace, si no preferente, al menos si amplia y relevante, para la enseñanza o explicación de la filosofía en niveles superiores, de la Metafísica aristotélica, sobre todo. Contra la preferencia indicada no creo que pueda aducirse ningún hecho, si bien es cierto que Gaos empleó también con fines propedéuticos, o alabó la idoneidad para ello, de textos como la Introducción a la filosofia de Nicolai Hartmann; en favor de la preferencia hablan tres puntos: $1^{\circ}$ el hecho mismo del empleo de los textos griegos, como lo muestra la Antología filosófica; $2^{\circ}$ las afirmaciones sobre su prerrogativa, como la siguiente expresión lapidaria: “... son estos textos llos griegos de la Antología] los más importantes de toda la filosofía griega, ma triz arquetipica de toda la filosofia occidental"; $3^{\circ}$ la publicación precisamente de esa obra; cosas, por lo menos estas dos últimas, que no pueden decirse con respecto a otros textos utilizados por él.

Más bien se podría argumentar aquí, que el hecho de la preferencia tiene una razón obvia, es decir, las virtudes incomparables de aquellos textos - sobre todo de Platón y Aristóteles- para la iniciación en la filosofía y que, por tanto, no se puede atribuir a la elección de ellos un valor especial; en otras palabras, sería algo normal en Gaos, como en muchos otros filósofos y maestros, la predilección por los filósofos griegos en ese respecto, pues ello respondería no a una inclinación especial del maestro, sino al valor interno de los textos. Es indudable lo relativo al valor interno, y aún más, que precisamente éste puede ser la causa de una particular inclinación; sin embargo, deben observarse dos cosas: primera, que en el maestro hispano-mexicano, como no en muchos, la inclinación aludida revistió características muy especiales, según lo manifiestan los tres puntos mencionados arriba; segunda, que, aun siendo los textos griegos quizá los más apropiados entre todos por sus valores, no obstante hay otros con virtudes, suficientes por lo menos, para la empresa, como por ejemplo el Discurso o las Meditaciones de Descartes, la Ética de Spinoza, el Ensayo de Locke, los Prolegómena de Kant, etc. De todo lo cual se deduce que la preferencia de Gaos por los textos griegos sí revela un aspecto positivo sobre lo que el pensamiento griego significaba en su enseñanza inicial de la filosofía.

( Ed. cit., p. 40. 
Antes distinguí entre el momento de la propedéutica y el de la explicación de textos en niveles superiores de la enseñanza, por ejemplo, en cursos monográficos y seminarios. En éste, como es comprensible, ya no se trata de escoger un texto por sus valores propedéuticos, sino simplemente de utilizarlo en orden a la formación filosófica, a la exposición de los temas clave de esta disciplina y al ahondamiento en los problemas fundamentales planteados por los grandes genios del filosofar. A la usanza europea, quizá sobre todo alemana, el doctor Gaos explicó en la mayor parte de sus cursos universitarios, excepto en la última década, obras filosóficas capitales, como de Heidegger en especial El ser y el tiempo, de Spinoza la Etica, de Kant Ias tres Crititicas, de Hegel la Fenomenologia del espiritu y la Lógica, de Husserl las Ideas, de Santo Tomás el De ente et essentia, de Aristóteles la Metafisica, etc. A esta última obra dedicó varios cursos, pudiendo analizar el texto con la mayor amplitud, resolver en general los graves problemas terminológicos planteados por el original griego, discutir los temas fundamentales ontológicos y teológicos ahí contenidos, explicar las numerosas dificultades filológico-históricas suscitadas por el más difícil de los escritos aristotélicos, etc.

En el conjunto de los textos explicados por el doctor Gaos en sus cursos, la filosofía griega, es cierto, sólo está representada, en lo que alcanzan mis noticias, por la Metafísica de Aristóteles - aunque es probable que haya dedicado algún curso a textos platónicos, como por ejemplo, al amplio pasaje del Sofista incluido en el libro sobre los Origenes de la filosofía y de su historia, o los mismos reproducidos en la Antologia, sobre los cuales el propio Gaos declara: "La obra puede ser utilizada como libro de iniciación en la filosofía tanto como de estudio más avanzado de la disciplina... por profesores y estudiantes en cursos de introducción a la filosofía, filosofía general, historia de la filosofía, teoría del conocimiento, ontología y metafísica, ética y hasta pedagogía - que para todo esto dan la variedad, amplitud e importancia de los textos inclusos en la obra." 7 Sin embargo, la Metafisica aristotélica ocupa en ese conjunto de filósofos y obras, a mi parecer, un lugar importantísimo, casi el principal, así por el número de los cursos dedicados, como por la preocupación e interés en resolver todos sus problemas, lo cual puede sin duda observarse a través de los diversos ensayos de traducción existentes, las numerosísimas anotaciones al texto, los trabajos para la formación de índices y glosarios, etc. ${ }^{8}$

Alguien diría que más bien lo importante para Gaos era la traducción y edición de la obra y no el trabajo didáctico. Yo recurriría con más sentido a su actitud primordial de maestro, concediendo a la publicación de lo explicado (téngase presente que casi todos o todos los libros del maestro son

7 Ibid.

8 A la persona especialmente interesada en comprobar estos datos y asertos se le facilitaría el acceso a los materiales existentes. Cfr. la nota que sigue. 
producto de cursos) el propósito de conservar la labor intelectual viva y extender su influjo en el espacio y en el tiempo; o también, el deseo de entresacar de la tarea didáctica los logros puros del pensamiento. Pero quizá lo más correcto sea, sobre todo con respecto a Gaos, no distinguir propiamente dos tareas o actitudes diversas, sino considerar una sola función espiritual: la reflexión, la meditación, el discurso, el pensar, que se expresá como enseñanza directa o como libro - ¿no es todo libro, aun el más abstracto y profundo, una comunicación, una enseñanza? ¿No es la posición más adecuada: pensar, discurrir e investigar lo que se enseña y enseñar lo que se piensa, discurre o investiga? Pensar para enseñar o enseñar para pensar, y más bien: pensar enseñando y enseñar pensando, vivientemente, creo que puede ser la mejor caracterización de la labor intelectual de José Gaos, maestro-filósofo.

$2^{\circ}$ El trabajo filológico más serio, profundo y extenso efectuado en México con relación a textos clásicos griegos se encuentra a mi parecer en la obra de José Gaos, y está en buena parte publicado, pero en su mayor parte inédito: lo primero puede verse en la Antología y en los Origenes; lo segundo, en las varias carpetas de reflexiones y anotaciones acerca de la Metafisica de Aristóteles. ${ }^{\circ}$

En este juicio no olvido los importantes trabajos de don Juan David García Bacca en el campo filológico-filosófico, que consisten en la traducción, introducida y anotada: $I^{0}$ de los diálogos Critón, Apologia, Eutifrón, Ión, Banquete, Fedro, Hipias Mayor, de Platón; $2^{\circ}$ de los Elementos de geometria, de Euclides; $3^{\circ}$ de los Memorables, Banquete y Apologia, de Jenofonte; y $4^{\circ}$ de la Poética de Aristóteles; ni tampoco se me escapan las valiosas aportaciones de don Antonio Gómez Robledo, quien trabajó acuciosa y profundamente en la traducción, introducida y anotada, de la Ética Nicomáquea y la Politica, de Aristóteles, así como en la de la Repriblica (de inmediata publicación), de Platón.

Aun frente a estas labores, sobre todo las del primero, creo poder decir con seguridad que se percibe más trabajo propia y estrictamente filológico en los comentarios, las disquisiciones y observaciones de José Gaos sobre la Metafísica de Aristóteles, sobre los Fragmentos de los presocráticos y sobre algunos textos platónicos. No es mi propósito enfrentar las calidades de los esfuerzos de uno y otros, ni mucho menos subestimar las de los dos autores citados; tampoco puedo presentar aquí un análisis siquiera breve de sus trabajos. Pero sí he creido necesario hacer una referencia a ellos, porque son indudablemente las otras dos aportaciones a la filología clásica filosófica más importantes aparecidas en México, y aun quizá en Iberoamérica, dignas de ser comparadas con la del maestro hispano-mexicano. ${ }^{10} \mathrm{Y}$ creo también no

- Todo este acervo fue entregado al Instituto de Investigaciones Filosóficas de la U.N.A.M., para su conservación, estudio y aprovechamiento en la edición de esta obra.

10 Otros trabajos importantes relacionados con la filología griega entre nosotros son 
hacerles agravio o injusticia a aquellos autores, al señalar en sus trabajos menores preocupaciones y disquisiciones filológicas.

Este juicio lo puedo apoyar desde diferentes ángulos: $1^{\circ}$ ninguna obra de la filosofía griega como la Metafísica aristotélica exige del comentador y traductor más trabajo filológico - y también filosófico, sin duda- para resolver la enorme cantidad de problemas planteados, y el doctor Gaos respondió ampliamente a esa exigencia, como puede verse ya en lo publicado en la Antología y en los Orígenes, y como se verá sin duda en los comentarios y anotaciones para la edición de la Metafísica entera (labor que honrosamente se me ha confiado); $2^{9}$ la proporción del aspecto "traductorio" mismo dentro de la dedicación a la filosofía griega es mayor en García Bacca y Gómez Robledo que en Gaos, en comparación con el aspecto filológico; $3^{9}$ el carácter de las introducciones en los trabajos de los dos autores citados, frente al de los ensayos y comentarios de José Gaos, es predominantemente filosófico, es decir, ellos se ocupan de analizar el contenido, exponer los temas y discutir los problemas doctrinales abstractos, digamos, dejando aparte o tratando sumariamente los aspectos relativos a los textos mismos, como son: constitución, trasmisión, tradición, historicidad y autenticidad, crítica, lenguaje, estilo, formulación, conceptuación, veracidad, etc., en una palabra, todo aquello que se comprende bajo el título de filológico y que se distingue y ha de distinguirse respecto de lo filosófico o histórico propiamente dicho.

Gaos, en cambio, se ocupa con gran amplitud de tales problemas, algunas veces aun en mayor proporción que de los filosóficos estrictamente dichos, como por ejemplo, en el extenso trabajo sobre los Origenes de la historia de la filosofía en Platón y Aristóteles, de carácter más bien filológico-histórico, en el cual discute a fondo los puntos de vista de Burnet, Diès, Taylor, Ross y Jaeger entre otros, aunque también contiene gran acervo de hermenéutica filosófica.

Pero donde se encuentra la mayor aportación filológica del maestro Gaos es, como decía, en los comentarios y anotaciones a la Metafísica de Aristóteles. Sin pretender que en esta labor el interés filológico supere al filosófico -lo cual podría inclinar la balanza en favor de que Gaos fuera en general más un filólogo que un filósofo-, es posible advertir en él no sólo una preocupación, sino un agrado, una fruición y hasta devoción en el tratamiento de los innumerables problemas y aspectos filológicos o filosófico-filológicos. Una anticipación fragmentaria y pëqueña de lo que haría él más tarde sobre la Metafísica entera -y que se mantiene inédito, como he dicho-, puede verse en lo publicado desde 1940 en la Antologia y más recientemente, en 1960, en los Orígenes. Con relación a lo manuscrito no es posible exponer

las traducciones del insigne Don Ángel Ma. Garibay y las del benemérito maestro Frangos, pero no se trata de obras filosóficas. El Dr. Nicol se ha dedicado también a la filosofía griega, la cual tiene grandes influencias en sus escritos filosóficos y cuya historia enseñó en la U.N.A.M. durante cerca de $3^{\circ}$ años. 
aquí ni siquiera un resumen - lo cual implicaria de mi parte un estudio, que aún no he llevado a cabo-; pero el repaso de las carpetas y el recuento de su contenido muestra un enorme material filológico que, al publicarse, probablemente constituya el estudio filológico más amplio y acucioso que se haya hecho en lengua castellana a una obra del pensamiento griego.

Otro lugar donde se contiene también valioso y extenso material filológico - asimismo inédito- sobre la Metafisica, es el ejemplar personal de Gaos de la monumental obra: Aristoteles. Darstellung und Interpretation seines Denkens, de Ingemar Düring," que muestra innumerables anotaciones marginales de puño y letra del maestro, en las que discute muchos de los puntos de vista de este gran filólogo sueco.

$3^{\circ}$ Dentro de la vastísima actividad de José Gaos la empresa traductora ocupa tal vez, junto con la docencia, el lugar más destacado. La simple lista de las diversas obras traducidas llenaría páginas. Por lo que respecta a los idiomas manejados, el principal es el alemán, al que siguen el griego, el inglés y el francés. Parece superfluo decir cuánto debe a Gaos la lengua española en el enriquecimiento de las obras fundamentales de la filosofía alemana moderna, especialmente de Heidegger, Hartmann, Husserl, Scheler, etc., pero también de la clásica, como de Hegel y Fichte - de Kant no se ocupó, seguramente por las traducciones de sus colegas y amigos M. Garcia Morente y J. Zubiri.

El segundo sitio en esa labor de traducción lo ocupa sin duda la lengua griega, tanto por la importancia de las obras traducidas, como sobre todo por la dedicación a ellas en tiempo e intensidad y tal vez también por el volumen de lo realizado. Los autores traducidos son Aristóteles, Platón y los presocráticos. De éstos traslada, como es usual, los Fragmentos; de Platón sólo partes de varios Diálogos; de Aristóteles, en cambio, la Metafísica entera, asi como un fragmento de la Etica.

Hablar de una traducción, o más bien, en el caso de Gaos, de un estilo y una forma de traducir, no en general mediante breves frases comunes $y$ estereotipadas, sino ampliamente, formulando los juicios en concreto y siguiendo de cerca la traducción misma, no es nada fácil, sobre todo cuando se trata de dar sólo una primera y breve visión de conjunto - de las relaciones de José Gaos con el pensamiento griego. Sin embargo, sí creo que pueden presentarse algunos rasgos fundamentales. En primer lugar, y en general, no parece difícil descubrir en Gaos una rara habilidad, un talento especial para la traducción, pues de otra manera no podrían explicarse las numerosas y extensas obras traducidas a lo largo de su vida, cantidad que en absoluto puede significar un detrimento de la calidad; es cierto que para inteligencia de lo anterior puede recurrirse a la práctica y al ejercicio des-

- Este ejemplar se halla en la biblioteca del Instituto de Investigaciones Filosóficas. 
arrollados en esa tarea durante más de 40 años. Sin embargo, el volumen de traducciones hechas por Gaos es tal - yo no encuentro entre los pensadores o filósofos de habla hispana, ni de ninguna otra lengua, alguien que se le compare-, que debe buscarse tras el ejercicio mismo, una disposición, un talento especial.

En segundo lugar, todavía también en general -es decir, en relación con el griego como con el alemán y las otras lenguas-, encontramos una preocupación y un interés manifiestos por esa tarea, que lo llevaron a consagrar muchísima parte de su tiempo con el fin de brindar a sus compañeros de lengua - todos los hispano-hablantes- algunas de las obras fundamentales del pensamiento filosófico universal. En esto se advierte una coincidencia con el aspecto pedagógico, o más bien: la tarea de traducción fue en la mayor parte de los casos una etapa previa necesaria para la labor de enseñanza de la filosofía en los diversos niveles.

En tercer lugar voy a referirme a los valores de la traducción misma. Aqui no quiero tocar sino un punto, que es central en Gaos y que toca la esencia de la traducción. Me refiero a aquello que mienta el vago y casi ya in-significante término de fidelidad. Yo prefiero llamar a esa cualidad esencial de la traducción autenticidä, y mejor, diafanidad. Llamar a una traducción diáfana, significa que se la considera un cristal transparente, a través del cual se ve y se obtiene lo contemplado, es decir, el original, en toda su plenitud de fondo y forma, y sólo sin aquello que por necesidad es inherente a cada lengua en su diversa naturaleza y que justifica precisamente la traducción misma. Y la llamo cualidad esencial, porque una traducción no diáfana, no es tal, ya que no cumple la misión y función de trasmitir, trasladar, trasponer lo dado en una lengua y un complejo cultural a otro lenguaje y conjunto.

Todas las traducciones de José Gaos revelan esa intención y poseen en alto grado esa cualidad. Sus comentarios orales sobre el asunto, en lo que yo sé y oí, lo expresaron así, y mi íntima convicción personal al respecto tiene en buena parte el origen en su enseñanza y sus ejemplos concretos de traducción. Respecto a El ser y el tiempo de Heidegger es bien sabido cómo llevó su propósito de diafanidad, si puede decirse así, hasta el extremo - las especialísimas características del sentido y estilo de la obra lo justifican-, pareciéndonos a veces leer alemán con palabras castellanas. Yo he comparado frase por frase su traducción total de Fichte, buenas partes de las de Heidegger y Hartmann y casi la totalidad de las del griego, y puedo decir -si esto tiene algún valor- que son las únicas que yo suscribiria con convicción y entusiasmo. En lo que se refiere a las traducciones del griego, he de recalcar que las suscribo frente a cualesquiera otras, aun frente a las inglesas (incluso la de Ross) y alemanas, y con mucho sobre las francesas e 
italianas y cualesquiera españolas. ${ }^{11}$ El principio, llamémoslo así, de la diafanidad deja sin duda cierto margen para variaciones accidentales $y$, en general, sólo ahí creo haber llegado a disentir del maestro alguna vez -disentimiento que por cierto debe contarse a su favor y no al mío.

A la traducción de dos obras dedicó el doctor Gaos, a mi juicio, el máximo interés y esfuerzo: $E l$ ser y el tiempo de Heidegger y la Metafísica de Aristóteles. Sobre ambas trabajó ya desde los años treinta, como dice él mismo en el Prólogo a la primera obra ${ }^{12}$ y en la Introducción a la Antología, ${ }^{13}$ que incluye dos de los libros de la segunda. El fruto completo de sus labores en torno a la primera apareció en 1951 con la publicación de la obra y de una extensa Introducción (después de ello Gaos no parece haberse ocupado nuevamente del tema). Sobre la Metafísica, en cambio, estuvo trabajando hasta su muerte en forma lenta, callada, pero fructuosa. La traducción dejada está completa; de muchos y amplios pasajes se tienen distintas versiones; con frecuencia, también, a través de esos cuarenta años (1930-1969) la estuvo retocando, corrigiendo, perfeccionando. El no haberla publicado, sin embargo, parece más bien deberse a la falta de un cuerpo de notas constituido y elaborado, así como de un estudio de carácter filosófico-filológico.

La Metafísica de Aristóteles fue objeto de explicación en varios cursos y sobre lo que éstos significaron para Gaos en orden a la traducción, podría usurparse lo que dijo él acerca de su labor sobre El ser y el tiempo: "Las clases en que se leyó la traducción me resultaron sumamente útiles por las mejoras que me aportaron el ponerla a prueba de los asistentes y las indicaciones de éstos, a las cuales debe principalmente la adopción de varios términos técnicos." 14 Sin embargo, no sólo los cursos, sino también otras actividades le ofrecieron gran ayuda en ésta como en aquella obra, según continúa diciendo ahí mismo: "Pero el traductor no ha cesado de modificar por su cuenta ni de recoger indicaciones ajenas, al hilo de la ampliación del conocimiento de las publicaciones... sobre Heidegger y aun de enseñanzas y comunicaciones verbales..."1s Con relación al aspecto del conocimiento y manejo de las publicaciones más recientes, recuerdo aquí lo que anoté más arriba sobre sus advertencias escritas al margen en la obra citada de $\mathbf{I}$. Düring.

También en forma semejante a como hizo con El ser y el tiempo, el maestro Gaos preparó el material para un amplio "fndice de traducciones". No creo fácil decidir cuál de las dos obras necesitaría más esa especie de vocabulario técnico, pero sí lo considero utilísimo en ambos casos. Pues, si

11 Especialmente de la Metafísica he revisado las alemanas de Gohlke y Rolfes, muy inferiores a la de Basengue, que me parece tan valiosa como la de Ross; respecto a las españolas, no merece mencionarse la vieja de Azcárate, y apenas tiene valor la reciente de Samaranch (Ed. Aguilar).

12 P. XII.

13 P. 35 .

14 P. XV.

15 Ibid. 
el novedosísimo uso terminológico de Heidegger, frente al del lenguaje ordinario y aun técnico de la filosofía, lo hacía indispensable, la terminología aristotélica de la obra fundamental no parece hacerlo menos, tanto por la novedad originaria, como por la pátina de la secular y rutinaria tradición. Tales índices, por otro lado, deben considerarse como parte complementaria de la traducción, ya que, según el maestro los concibió y realizó, tienen el fin de explicar la traducción misma, precisando los términos usados y distinguiendo diversos usos, contextos y acepciones. Sin embargo, en otro aspecto, no es un simple vocabulario, ya que partiendo de los problemas terminolón gicos se adentra ei autor en probiemas temáticos.

El paralelo entre ambos trabajos, como he venido repitiendo, es manifiesto, y también al índice de la Metafísica podemos aplicar lo que dijo Gaos acerca del puesto a la obra de Heidegger - sobre todo a falta de explicaciones explícitas con respecto al primero: "Este índice es menos y más que uno de materias. Menos, porque no indica ni todas las materias de la obra..., ni todos los lugares de cada materia indicada... Más, porque la agrupación de las expresiones por familia, la disposición sinóptica dada a los artículos y las explicaciones añadidas en los casos que parecieron indispensables o particularmente ilustrativos de los problemas de la traducción y justificativos de los recursos a que se acudió para resolverlos, ofrecen o permiten confrontaciones entre las materias de la obra que pisan los umbrales del comentario." 16

Si buscamos la razón por la que José Gaos escogió de un lado la Metafísica de Aristóteles y de otro El ser y el tiempo de Heidegger para dedicarles su máximo esfuerzo traductivo, quizá podamos encontrarla no tanto en la importancia general de esas obras - que sin duda la tienen de primerísimo rango, sobre todo la Metafísica一, sino en ciertas características que las hacen particularmente difíciles, como pocas en la historia de la filosofía, y sobre todo aptas para exigir del traductor el máximo rendimiento. No creo que en la filosofía griega pueda señalarse ninguna comparable, excepto tal vez el Parménides de Platón, los Analíticos del mismo Aristóteles o las Enéadas de Plotino; y en lo que se refiere a la filosofía contemporánea, realmente no se me ofrece alguna obra comparable, no por cierto en importancia, sino en dificultad, sutileza y hondura. La razón, por tanto, fuera de una inclinación o un interés personales, estaría en que Gaos quiso acometer y llevar a término en plan cientifico una tarea, a la que nadie se había atrevido en cuanto a El ser y el tiempo, y la que era necesario, indispensable abordar en cuanto a la Metafisica, por no existir ninguna traducción de valor siquiera mediano o suficiente en toda la historia de la lengua española. ${ }^{17}$

16 P. XVIII.

17 Me refiero a la de $P$. de Azcárate, que, desgraciadamente, por no haber otra, se reproducía antes con frecuencia. La Ed. Aguilar sacó recientemente una de Samaranch, que apenas si sirve para los estudiantes. 
Decía arriba "en plan científico". Porque sobre todo estas dos traducciones del maestro Gaos ofrecen ese valor. Aquí se ve con toda claridad, a través de los prólogos, los índices, las notas, los comentarios - y de la traducción misma, desde luego-, que Gaos traduce sobre bases metódicas y con preocupaciones filosóficas. No son en absoluto labores de divulgación o simple información - como lo son casi todas-, sino trabajos científicos, seguidos con profunda conciencia de la tarea y llevados a término después de reflexión, análisis y estudio, no sólo en cuanto a la terminología y sus prablemas concretos, sino en cuanto a la idea y al sentido, así de los pasajes individuales como de la obra total.

$4^{\circ}$ El aspecto doctrinal o ideológico de la presencia del pensamiento griego en José Gaos es sin duda el más difícil de descubrir y señalar, no precisamente con relación al trabajo o a la actividad filosófica misma sobre el pensamiento y las obras griegas - lo cual puede verse fácilmente en diversas de sus publicaciones-, sino por lo que respecta a la influencia efectiva, a la asimilación y a los resultados. En este punto es donde los estudios sobre la dirección o escuela filosófica del maestro ofrecerían mucha luz. Quizá hasta el año 6o el historicismo nos sirva como punto de referencia. A partir de ese año el doctor Gaos dejará los trabajos propiamente de exposición y comentario de las obras de otros filósofos - actividad que lo ponía en relación estrecha con el historicismo-, para consagrarse en una forma plena y casi exclusiva a la elucubración y presentación de su aporte sistemático al pensamiento filosófico. El libro De la filosofia, publicado en 1962, pero que con-

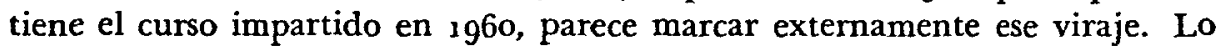
dicho debe entenderse más bien en el sentido de que desde ese año habrá una dedicación quizá total a la labor indicada, pero no en el de que antes no la haya habido. Muestras, y por cierto amplias aunque no publicadas aún, de su reflexión filosófica personal, las tenemos en varios cursos, sobre todo de metafísica, preparados y lefdos ya a partir de los años cuarenta.

Por otra parte, es bien sabido que el doctor Gaos, en especial dentro de las dos últimas décadas, movido sin duda por urgencias interiores, manifestaba con insistencia el propósito de elaborar su propio pensamiento, de culminar una vida entera dedicada a la filosofía con una concepción personal sobre ésta. Aunque en manera alguna le pesara ocupar su tiempo en la docencia, la dirección de tesis y la traducción, sin embargo, sí consideraba que su misión quedaría en gran parte incumplida, si no mostraba sus propias ideas y puntos de vista.

La presencia del mundo griego en José Gaos en el aspecto específicamente filosófico puede muy bien dividirse en dos momentos, o también, localizarse en dos puntos: el historicismo y la filosofia sistemática. Por esta última entiendo las diversas disciplinas tocadas por el maestro en los libros 
De la filosofia y Del hombre -éste de próxima aparición-, por cierto no muy definidamente, pero que pueden confluir en la lógica, la gnoseología y la metafísica. En cuanto al historicismo, y con el propósito de distinguirlo del otro punto, creo necesario recordar, por una parte, que no fue doctrina original suya -excepto tal vez su arranque o aplicación al pensamiento de lengua española-, y por otra, que pueden aducirse razones para no encuadrarlo en la filosofía sistemática, por ejemplo, la de ser propiamente una aplicación de ésta como filosofía de la historia. Y por lo que respecta a la cronología, al menos según lo publicado, la división no parece tan exacta, pues entre el año de 1945 -fecha del Prólogo al libro Filosofía de la filosofia $e$ Historia de la filosofia- y el de 1960 (curso De la filosofia) no se ofrecen datos suficientes a fin de señalar el predominio de una $u$ otra preocupación - aunque, como se dijo antes, ambas se muestran tal vez desde que se constituyó la vocación filosófica de Gaos. ${ }^{18}$

La preocupación historicista, que verosimilmente predomina hasta la mitad de la sexta década - dejemos unos cinco años para la constitución inmediata del curso $D e$ la filosofia-, parece naturalmente conectada con las otras actividades que desarrolló en esa época el maestro - diversos trabajos personales, así como las muchas y valiosas tesis dirigidas, en torno al tema central de la Historia del pensamiento en los paises de lengua españolay dependiente, como se comprende, de las influencias inmediatas y mediatas de Ortega. Dentro de esa preocupación básica la influencia del pensamiento griego puede considerarse como determinada por la búsqueda consciente del enlace con los primeros orígenes o de la confirmación en éstos de sus propias convicciones. La búsqueda de esos dos puntos —enlace y confirmación- no es en modo alguno incidental, ni realizada simplemente a título de ejemplo, sino que la creación y concepción de la historia en Grecia llegan a ser vistas por Gaos como fundamento y parte esencial de un desarrollo que con plena conciencia sólo culmina en el historicismo. En muchos pasajes del libro Origenes de la filosofia y de su historia, o de algunos artículos de la obra Filosofia de la filosofía e historia de la filosofía ${ }^{10}$ o de la primera parte de la Antologia filosófica, cuyo título es "El historicismo y la enseñanza de la filosofía", puede advertirse la importancia que concede Gaos a las doctrinas sobre la historia de los tres autores estudiados - Herodoto, Platón y Aristóteles-, como antecedentes fundamentales de la moderna concepción de la historia de la filosofía y de la filosofía de la historia.

Para conocer directamente algunos puntos concretos, en los cuales Gaos precisa honda y sutilmente ciertos aspectos de la conexión con las visiones

18 En la Introducción a la Antologia, en diferentes artículos y en papeles manuscritos de sus cursos hay datos para confirmar el aserto.

19 Por ejemplo: "Sobre la filosofía de la filosofia", "El concepto de la filosofía", "Existencialismo y esencialismo", etc. 
de los griegos, acerquémonos a algunos pasajes importantísimos del libro Origenes de la filosofia y de su historia. En esta obra se contienen dos trabajos: el primero versa sobre la aparición y constitución de la historia en Herodoto; el segundo sobre las aportaciones de Platón y Aristóteles a la formación de la conciencia histórica en la historia de la filosofía. Considerémoslos en ese orden.

Tres reflexiones me parecen las más dignas de destacarse en el estudio inicial. La primera se ocupa en señalar la procedencia y "consistencia" de la historia en y de la naturaleza humana, y más allá la función o facultad esencial que la realiza: "Pues bien, sólo porque en el hombre, individual y colectivamente se dan naturalmente, por obra de su naturaleza -mejor, como la obra, como la acción o actividad en que su naturaleza misma consiste-, estas funciones, este memorar espontáneo, este conmemorar, este historiar, antes de toda historia en cualquier sentido especffico, antes de todo historiador, sólo por esto es posible que de estas funciones naturales suyas haga la "doble" naturaleza humana objeto, reflexivo, de sus intenciones, y convierta su natural memoria en historia como arte, profesión, género literario, ciencia. La historia se nos presenta así como la emergencia de una figura artificial o artificiosa $o$ artística del seno de la historicidad o memoricidad humana. Herodoto es la personalidad genial que instituye en forma de vida, profesión o técnica y decanta su obra objetiva una función que todos los humanos llevan a cabo cotidianamente sin compromiso alguno ni pizca de técnica." 20

La segunda trata acerca de los elementos esenciales del ser humano en cuanto histórico, uno de los cuales fue establecido por los griegos: "El hombre es un ente hecho de tiempo y de palabra, que se combaten en él. Su ser es la pugna entre estas dos potencias de él constitutivas. Los griegos precisamente vieron bien que el hombre se definia por el logos, por la palabra, interior -razón-y exterior: animal racional, animal de razones... Los modernos ven bien, traduciendo en filosofía una inspiración religiosa cristiana y judia, que el hombre se define asimismo por su temporalidad, por el tiempo. Es menester que a nuestro turno veamos la historia entera de la filosofía y aun de la Humanidad como la gigantesca, descomunal contienda entre el Tiempo y el Verbo en el hombre. $O$ si se prefiere en griego: como la gigantomaquia de Cronos, devorador de sus hijos, y el Logos, que va a pretender sustituirle, pasando por Zeus, en la monarquía del universo. Para comprobarlo así basta confrontar Homero y Heráclito." 21.

En la tercera hace Gaos un llamado sobre la complementación metódica que el pensamiento actual debe emprender basándose en la doctrina del primer historiador: "La comprensión de Herodoto no puede ser, pues, acabada sin un esbozo siquiera de fenomenología de este aspecto de la naturaleza

20 Obra indicada, p. 39 .

21 Id., p. 34 . 
humana. Bien entendido, en efecto, que de las muchas cosas que cabe reconocer en este complejo fenómeno y que habría de decir, sólo recogeremos aquí aquel mínimo, bien que medular, absolutamente indispensable a la consecución de nuestros propósitos. $\mathrm{Y}$ aprovechemos la ocasión para fijar la atención sobre este caso y ejemplo de la efectiva conjunción de un método de interpretación_de-expresiones históricas y-el_método fenomenológico. A este último toca suministrar las bases últimas para la inteligencia de los fenómenos históricos conocidos por su expresión, y traducir en términos explicitos esta misma inteligencia." 22

Del segundo trabajo contenido en la obra que consideramos, el cual bien podría constituir por sí un libro aparte y es un extenso y profundo tratado de filología filosófica, extraigamos también tres párrafos, de mayor amplitud y donde la conexión aludida se destaca más claramente. El primero tiene en apariencia sólo una finalidad aclaratoria de las relaciones entre la filosofía y la historia: "Conclusión: se impone echar la vista a la filosofia anterior a Platón y Aristóteles y a estos mismos, o abordar la historia de la Historia de la filosofia hasta Aristóteles, o la composición de la Historia de esta Historia; para precisar los comienzos de la Historia de la filosofía, la naturaleza o esencia de esta Historia, su relación con la filosofía, y, como temas conexos o implícitos, la relación de la Historia de la filosofía con la historia de la filosoffa, la naturaleza o esencia de esta historia, la relación de la filosofía con esta su historia, la naturaleza o esencia de la filosofía misma [?] precisar, hasta donde sea posible, y donde no se pueda más, apuntar en la dirección que se avizore, si es que se vislumbra en la lontananza alguna." 23

Pasando al segundo párrafo, puede decirse que al planteamiento anterior se responde páginas adelante, al afirmar una relación esencial, más aún, una identidad entre filosofía e historia de la filosofía; reflexión que culmina al establecer el fundamento último de aquella relación en el plano ontológico: "La filosofía se hace inhalando una atmósfera de conciencia, de saber históricos, de Historia de la filosofía. Esta Historia, inhalando la atmósfera de una filosofía. La Historia de la filosofía es filosófica $\rightarrow$ si es Historia de la filosofia. Lo enseñó definitivamente Hegel. Pudo haberse aprendido desde Platón. Y la filosofía de la historia de la filosofía, de la filosofia misma, requerida por la Historia de la filosofía, debe tener la plenitud de una filosofía plena, una metafísica debe acabarla. La filosofía de la historia de la filosofía en el Sofista desciende a la ontologia; y en ésta, a los fondos últimos. La ontologia de Platón, su cima, o su mayor profundidad en el Sofista principalmente, tiene, en efecto, un doble interés. / $\mathrm{El}$ interés ontológico puro, para la historia y el contenido teórico de la ontología, que de antiguo se ha reconocido en ella. La primera ontología, particularmente la primera apo- 
rética ontológica, es la de la primera parte del poema de Parménides. La segunda, es la del Sofista, dirigida contra la primera, y más amplia y honda que ésta... / Mas el interés de la ontología del Sofista pertinente aquí no es el que tiene para la historia y para el contenido teórico de la ontología. Es el que tiene para la filosofía de la Historia de la filosofía y para la filosofía de la filosofía. El de enseñar que la filosofía en su historia funda sobre el ser y el no-ser en la realidad óntica, y que por esto la comprensión de su historia, de sí misma, por la filosofía, sólo es plena cuando es comprensión ontológica... Porque la filosofía se presenta como siendo la conciencia de sí extrema, acabada, absoluta. Por todo, Platón puede estimar que funda, más que de nuevo, propia y definitivamente, la filosofia, al alcanzar por primera vez la conciencia ontológica, plena, de si misma, en él. Dentro de este interés de la interpretación ontológica de la filosofía en su historia, en general, es un punto de interés singular el del no-ser en la interpretación. A Parménides lo rectifican ya los physici recentiores. Pero acabada, definitivamente, sólo Platón." 24

Un tercero y también amplio párrafo puede considerarse justamente como síntesis apretada de la concepción historicista de José Gaos, hecha precisamente en directa relación con sus orígenes en Grecia y destacando de modo especial la continuidad de la problemática en el pensamiento de nuestra época: "Estas relaciones [las de la filosofía y su historia] han sido efectivas, aunque no conscientes en su posible plenitud, todo a lo largo de la historia de la filosofía. Para los orígenes de ésta, ya lo habrá mostrado el presente trabajo. Han acabado por ser problema plenamente consciente para la filosofía, de la filosofía, en la actualidad. Problema central. Desde sus orígenes también, la conciencia de sí, el saber de sí, el problema de sí, es constitutivo de la filosofía. El presente trabajo lo habrá mostrado igualmente: Heráclito, esforzándose por distinguir su sabiduría de lo que no era ella, pero podían confundir con ella, y por imponer la superioridad de ella; Platón, ahondando en las condiciones de posibilidad radicales de sofística y filosofía; Aristóteles, definiendo la sophia e historiando sus orígenes filosóficos y su desarrollo. Pues bien, el problema de sí es más que nunca el constitutivo de la filosofía en la actualidad. La conciencia de su historicidad no ha sido para la filosofia del pasado plena como lo es para la de hoy. Al hacerse plena para ésta le ha planteado el problema de sí como no se le había planteado a la filosofía del pretérito. A ésta no se le planteaba en términos de historicidad plena. En términos tales se plantea a la de hoy. La historicidad misma de los términos del planteamiento requiere historicismo en la resolución: por medio justamente de la conciencia, del saber de la historicidad de la filosofía; de la Historia de la relación de la filosofía con su historia, de la conciencia, del saber históricos que la filosofía ha tenido

24 Id., pp. 116, 117, 118. 
de sí; de la Historia de la Historia de la filosofía. Fundamentales en la historia de la Historia de la filosofia por la cercania a los origenes, "que en rigor culminan en ellos; capitales en la misma historia toda por su altura y hondura filosófico-histórica, los textos traducidos en el presente volumen resultan fundamentales y capitales para la resolución del problema." 25

Si el contacto con los filósofos griegos y su influencia han aparecido con bastante claridad en relación al historicismo y a través de las palabras mismas de Gaos, no resulta algo semejante con respecto a la filosofía sistemática. Al recorrer los indices de las dos obras donde se localizan las aportaciones sistemáticas del maestro al pensamiento filosófico: De la filosofía y Del hombre - la primera publicada en 1962 y la segunda de próxima aparición en este mismo año-, no se advierten temas donde directamente pudieran hallarse influencias específicas, trascendentes o considerables, de la filosofia griega. Es cierto que pueden verse en ellos, así como encontrarse a cada paso en la lectura de las obras mismas, los conceptos y términos fundamentales y tradicionales de la lógica, la metafísica, la gnoseología y la antropología occidentales, clásicos desde Grecia; pero sería erróneo pretender demostrar con ellos tales influencias. En estos dos libros -y considerando el segundo como una continuación, un desarrollo y profundizamiento de la temática del primero (que debería rematar en una antropología filosófica, la cual aparecería en Del hombre) - la influencia básica es de la fenomenología -Husserl, Heidegger-, así como de la moderna filosofía del lenguaje; influencias importantes y cercanas son también Kant, Hume, Leibniz, Descartes, la escolástica; influencias lejanas o mediatas serfan Aristóteles, Platón, Parménides.

En el libro De la filosofia hay unas 6o referencias a los filósofos griegos, divididos entre Aristóteles (32), Platón (12), Parménides (6) y luego 1 cada uno: Sócrates, Heráclito, Meliso, Plotino, filósofos griegos, filósofos antiguos; o los términos hypokeimenon y ousia. Casi todas estas referencias tienen un carácter circunstancial, pues son breves alusiones a hechos o doctrinas, que aclaran sólo algún punto histórico, pero no significan un elemento importante ni menos esencial dentro del sistema o desarrollo ideológico. Unas pocas sí encierran afirmaciones de dependencia y continuidad en el pensamiento actual, el suyo, con respecto al antiguo griego; se trata, además, por lo menos en algunas, de ciertos puntos doctrinales básicos, o de reconocimientos valiosos sobre una influencia general. Voy a presentar las más importantes, reproduciendo los pasajes alusivos.

A mi juicio, el punto de mayor trascendencia, de los seis cuyos textos recogeré, es el contenido en la siguiente reflexión, la cual se ocupa de las concepciones fundamentales en la antropología filosófica, cuyo origen se hace

25 Id. pp. 193-4. 
remontar hasta Aristóteles: "Ĺa constitución de éstos [de los sujetos] se articula en dos dimensiones, determinantes de las dos escuelas cardinales de Antropología Filosófica que deben reconocerse en el estado actual de esta disciplina filosófica, la 'principal' de la filosofía de nuestros días... / La subjetividad es, en una dimensión, una 'estratificación' de 'grados'; en otra dimensión, una 'cinemática' 'formal'. / La primera dimensión es la iniciada por Aristóteles con sus almas vegetativa, sensitiva, racional, y venida hasta las llamadas eclasificaciones de los fenómenos psíquicos» incluso del dia de hoy. / La segunda dimensión es la iniciada por Aristóteles con la distinción entre «movimientos y acto», si es la que ha venido a ser la concepción existencialista del hombre. / Lo propio de la primera dimensión será tema parcial del tema de la clasificación de los existentes bajo el punto de vista de la presencia... / Lo propio de la segunda dimensión será tema parcial del tema de la razón de ser de la razón pura por la razón práctica..." 26

Reflexionando sobre otro punto, también de gran importancia en el panorama de la filosofía actual y relativo asimismo a tema antropológico y psicológico, enlaza el doctor Gaos una doctrina heideggeriana, a través de una determinada tradición, en último término con Aristóteles: "En general, entre percepto, recuerdo y previsión de si hay modos relativos de continuidadidentidad de la sustancia, del yo, que parecen hacer imposible la aparición y desaparición de ésta, posible únicamente la de modos; y hay, no sólo modos, sino una sustancia concebida como 'propia' por su unión sui generis con la propia psique, el propio cuerpo, que tiene en tal continuidad la función básica que corresponde a su lugar de percepto central y continuo en el campo de la percepción. / Ahora bien, ambos pasos pueden interpretarse, a su vez, como dados sobre la materia o sobre el alma sustancial, según las concepciones tradicionales, o sobre nada, según la que parece ser la concepción de Heidegger, o en todo caso por éste inspirada al existencialismo de la filosofía de nuestros días, y aún a más de ésta, aunque a Heidegger a su vez se la inspirase una tradición filosófica que remonta por lo menos desde Pascal y Descartes hasta por lo menos Séneca, si no Aristóteles. Es la concepción de la existencia humana como creatio continua y continua annihilatio, como complexión de potencia y acto reiterada a cada instante." 27

Otro punto de vista heideggeriano, ahora sobre tema ontológico, considera Gaos para señalar nuevamente una conexión con Aristóteles, si no di: recta, sí por lo menos indirecta a través de la filosofía escolástica, tan deudora del Filósofo: “....el hecho de que digamos 'existe', 'existente', 'existencia', notifica que natural, espontánea, primariamente, concebimos la existencia como un modo y que lo sustantivamos; sería menester, pues, mostrar que tal manera de concebir no sería la justa. Pero, entonces y en segundo

26 Obra indicada, pp. 234-35.

27 Id., p. 977. 
término, sería menester mostrar esta manera justa, como se ha intentado desde Aristóteles, o desde la escolástica, hasta la neoescolástica, inclusive - Heidegger: 'principios' del ente- para nosotros: del existente -como la esencia y la existencia - para nosotros: el ente y la existencia - no son a su vez entes- para nosotros: existentes; el ser - para nosotros: la existencia- es lo único que no sería ente alguno - para nosotros: existente alguno." 28

Con visible énfasis el doctor Gaos llama la atención sobre una actitud censurable de los filósofos contemporáneos con respecto a la tan conocida y fundamental doctrina aristotélica acerca del modo de predicación del ser; llamada de atención que no puede entenderse sino en el sentido de que él, en su concepción ontológica propia de un filósofo de nuestro tiempo, considera tal doctrina como válida y su adhesión a ella como necesaria. He aquí su reflexión: "Aristóteles no se cansa de repetir que "el ser se dice de muchas maneras', según se traduce tradicionalmente. $A$ pesar de aviso tan repetido, antiguo y autorizado, hasta en los ontólogos actuales más autorizados a su vez y a la vez más aristotélicos, se advierte la mayor confusión terminológica y conceptual, con las forzosas consecuencias: en unos casos, la ambigüedad y hasta el 'multívoco': no se logra precisar en cuál de varios sentidos posibles aislada y contextualmente deba tomarse un término en un pasaje; en otros casos, los juegos, no de palabras, sino de las ambigüedades y multívocos de éstas, los juegos de conceptos y los paralogismos. IY asi se pretende resolver el problema del ser y del conocimiento de éll -que ni siquiera puede plantearse con rigor sin rigor terminológico." 2

Una nueva referencia a Aristóteles la hace Gaos en torno al punto de partida fundamental para la definición de la filosofía, el cual, como puede verse en el contexto del pasaje que citaré, sigue siendo a su juicio, a través de los momentos culminantes de la historia de la filosofía, la base de las concepciones posteriores y actuales sobre su esencia: "La definición de la Filosofía por medio del concepto de 'principio', 'arquetipica' en y desde Aristóteles, y este concepto, son reveladores: 'ciencia de los principios'. 'Ciencia', documentando lo dicho acerca de los filósofos como hombres de ciencia; pero 'de los principios', revelando la diferencia entre los filósofos y los hombres de ciencia no filósofos. 'Principio' traduce 'arché'. Esta palábra griega es de la familia de la palabra 'arconte'. 'Principio' es palabra de la familia de las palabras 'principal' y 'principe."”

Finalmente consideremos una alusión a la doctrina fundamental de Platón: la de las ideas. La conexión implicada por Gaos aquí confrontando al filósofo griego con Husserl, no es positiva, es decir, no está en que el filósofo germano $-y$ eventualmente Gaos con él- siga, a su juicio, una tesis

28 Id., pp. 393-94.

29 Id., p. 254 .

30 Id., p. $44^{\circ}$. 
platónica, sino en que ésta se considere como contrapartida, y en ello influyente, de las doctrinas actuales. Leamos su reflexión: "Los existentes ideales no serían, pues, metafísicos en ningún sentido propio o riguroso -en contra de la tradición que, desde Platón, hace del mundo de las ideas un mundo metafísico, sin duda por no hacer lo que parece más justo: extender, con Husserl, el positivismo a lo ideal, concebir como metafísicos puramente los existentes que no pueden ser fenómenos en ningún sentido. Pero ellos y el tiempo tendrían esta peculiar 'trascendencia' desde los existentes fenoménicos hasta los metafísicos. De no haber existentes ideales, sino puros conceptos, puros actos psíquicos de pensar, habria que decir que los sujetos fenoménicos y los metafísicos pueden tener pensamientos iguales." 31

Como últimas observaciones sobre el tema tratado en este párrafo, digamos que existen influencias más o ménos claras, pero muy generales, del pensamiento griego sobre José Gaos en algunos temas fundamentales de la filosofía, como éstos: 1. la definición aristotélica del hombre en cuanto animal racional, que parece ser base profunda de su concepción antropológica (según se verá, al publicarse la obra, en la Lección Primera de Del hombre); 2. la teoría de las categorías y conceptos relacionados, como los trascendentales, los universales, los predicables, etc.; 3. la teoria platónica de las ideas, en sus aspectos ontológico y gnoseológico (como también se verá en los primeros párrafos de la Lección 22 de Del hombre); y otros menos importantes. Sin embargo, no parece poder señalarse un influjo específico y directo, así fuera negativo o por contraposición, de Aristóteles o Platón -que sin duda están presentes de manera general e indirecta-, sino más bien a través de la escolástica, o como referencias a temas clásicos de la filosofía universal.

La conclusión de los textos, datos y consideraciones presentados en este provisional ensayo de aproximación al tema propuesto, creo que puede y debe ser que el pensamiento griego desempeña en el filosofar de José Gaos, a lo largo de su vida, un papel no sólo notable y de gran importancia, sino, esencial -fácticamente- en este sentido: que de hecho la inspiración en los filósofos griegos fue elemento decisivo al constituirse su vocación filosófica, y las doctrinas e ideas de aquéllos formaron parte vital e integrante en su concepción filosófica. El uso del término "esencial" podría suscitar dificultad; sin embargo, yo no lo entiendo como necesario a priori; tampoco como único, ni siquiera como principal, sino como uno de los elementos constitutivos de hecho, que a posteriori resultan ser tales y como algo que determinó en una cierta medida, tal vez modesta, la fisonomía de su pensamiento.

Entre los pensadores o filósofos de lengua española, creo que sólo en Zubiri -en cuanto a la constitución profunda de su pensamiento- o en García Bacca -en cuanto a los antecedentes y a la actividad expositiva y 31 Id., p. 294 . 
traductora- podrían encontrarse casos paralelos al de Gaos con respecto a la influencia de los filósofos griegos. Fuera de éstos, en ningún otro: lo cual sería no sólo un distintivo, sino un aspecto valioso de su pensamiento por el enlace con los padres del filosofar.

Tal vez de este ensayo sólo se saque una impresión sobre mis asertos. Sin embargo, estoy convencido de que otros estudios más profundos y completos presentarán una imagen semejante, sólo que más nítida, precisa y fundamentada.

INSTITUTO DE INVESTIGACIONES FILOSÓFICAS

BERNABE Navarro

Universidad Nacional Autónoma de México 